\title{
Linguagem: presença significativa na identidade e no progresso de um povo
}

\author{
Elizabeth Maria Chemin Bodanese \\ Professora do CEFET-PR, unidade de Pato Branco. Mestre em Ciências Sociais \\ Aplicadas - Área de Concentração: Recursos Humanos (UFPR)
}

\section{Neri França Fornari Bocchese}

Professora do CEFET-PR, unidade de Pato Branco. Mestre em Ciências Sociais Aplicas - Área de Concentração: Economia (UFPR)

RESUMO: O presente artigo destaca a importância da literatura que, através da linguagem, possibilita a formação e a expansão do conhecimento no registro da história de um povo.

ABSTRACT: The present article points out the importance of literature that, through language, enables the formation and expansion of knowlege concerning the record of people's history.

"...aquilo de que a língua fala, em definitivo e sempre, é a sociedade, seu irredutível universo de discurso."

(LOPES, 1974, p.43)

Quando se fala ou se escreve, procura-se comunicar intenções, estabelecer contatos verbais com ouvintes ou leitores, produzir, pela articulação das palavras ou frases, significações dotadas de intencionalidade que ganham sentido pela 
inferência dos destinatários criando dessa forma unidades discursivas. Entende-se, assim, a linguagem como sendo o próprio pensamento em ação, que permite ao homem interagir com a realidade circundante.

O homem constrói a História em mutualismo, ou seja, dá e recebe benefícios ao seu crescimento à medida que escreve, participa e lê o mundo a sua volta. Afinal, o homem é um ser social. Desde a passagem do seu estágio animal para o hominal buscou se interar com seus semelhantes para solucionar os problemas surgidos ao longo da vida. E o que garantiu a sua sobrevivência e o seu avanço em direção ao processo de criação da humanidade foi a capacidade dele comunicar-se.

Assim, o uso de uma linguagem possibilitou importantes descobertas ao longo do tempo e do espaço, propagando-as às sucessivas gerações e desse modo, servindo de ponto de partida a novas descobertas. Garantiu-se, portanto, pela comunicação, a continuidade e a expansão de experiências coletivas - desencadeando o primeiro processo educativo implantado pela linguagem.

Cumpre-se aqui estabelecer a diferença fundamental entre o instrumento e o símbolo que o representa: o instrumento é concreto e material, enquanto o símbolo é psíquico. Este, age como mediador entre o sujeito (Homem) e o objeto (Instrumento), atingindo o sujeito na sua capacidade pessoal (psíquica) e transformando-o pela sua própria iniciativa e/ou vontade.

O ser humano é único. Somente ele é capaz de receber experiências e aplicá-las de acordo com as suas necessidades, reestruturando-as de forma a aperfeiçoálas transmitindo-as aperfeiçoadas e adequadas ao momento histórico às futuras gerações para que sejam aplicadas e reprocessadas de acordo com a visão de mundo no momento histórico vivenciado.

A partir dessa visão, as descobertas são frutos de reflexão e processamento de experiências vividas, o que nada impede que dentro de uma mesma sociedade se tenha respostas diversas a um mesmo problema e, dentro dessas repostas, uma mais adequada às necessidades dos grupos.

Conforme Clifford Geertz (1989), o homem é um animal amarrado a teias de significado, que ele mesmo teceu, sendo a cultura essas teias. 
Considerando cultura como a soma de conhecimentos, idéias, realizações materiais, valores espirituais, essas experiências e visões pessoais juntas formam um acervo de múltiplos aspectos que, transmitidos horizontalmente para os contemporâneos, e verticalmente de gerações a gerações ao longo do tempo, permanecem enquanto atendem às necessidades grupais ou pessoais. Convém ressaltar que encontram-se culturas em estágios diferentes dentro de uma mesma época, pois a capacidade de cada pessoa e as suas condições gerais de vida diferem de um lugar para outro.

E, quando as palavras passam a ser transmitidas de gerações a gerações, no seu conjunto, elas passam a ser literatura, configurada através de uma língua natural: a linguagem verbal - o verbo. "No princípio era o Verbo, e o Verbo se fez carne". Jo 1,1

Isso comprova a importância da linguagem no Ser, pois não há como se identificar enquanto povo com a sua cultura própria sem a interferência da linguagem. Esta, quando verbal, é sempre passível de novos arranjos, é viva, pois cria e recria variados tipos que passam a ser a própria cultura de um povo, a qual toma corpo e propicia condições para que um determinado grupo humano se identifique enquanto povo.

Essa linguagem, à medida em que vai se fortificando passa a ser a expressão escrita, a Literatura. Nesta, a língua natural não é simplesmente usada para comunicar fatos relevantes do cotidiano, é usada sim, para comunicar a história cultural de um povo, construindo o que se pode chamar de obra literária, a mensagem. E isso diferencia a Literatura que é uma Arte, das outras Artes, pois através da língua natural constrói-se a palavra que quando carregada de expressão não se perde no seu uso, mas permanece na obra literária.

As construções linguiísticas, populares e eruditas retratam o passado e o presente, pois ao narrar a fala dos personagens, a Literatura apropria-se da História e, ao utilizar tipos diferentes de linguagem está sendo coerente com a natureza de suas histórias e de seus personagens.

Dessa forma, necessário se faz considerar a obra literária como um todo. Entendê-la no seu contexto, pois frases isoladas podem até ter um significado 
individual, porém, o sentido total da obra não se reduz apenas a uma parte, porque a mensagem é a obra em sua totalidade, que não necessita da presença física do autor porque a palavra permanece no tempo e no espaço, possibilitando ao leitor diferentes leituras no seu contexto histórico-social.

Assim, a obra literária é um comunicado, uma mensagem a vários interlocutores que dela farão uso com diferentes leituras, de acordo com cada meio e com cada época. $\mathrm{O}$ autor, de certa maneira, seleciona entre os temas que a sociedade lhe oferece, aqueles que interessam a ele. Isso faz com que a obra literária surja como um produto intencional de uma vontade criadora que se concretiza em um determinado momento, dentro de um determinado contexto histórico-social, que dispondo de autonomia em relação às circunstâncias do momento em que está sendo criada, não deixa de apresentar traços que remetem-na ao criador e ao contexto. E sem deixar de ser autônoma, traz consigo as marcas individuais e pessoais do autor, tanto quanto as marcas sociais.

A Literatura, produção que se vale da língua que utiliza, bem como dos assuntos dos escritores, da criatividade e imaginação e do ato da leitura enquanto recurso artístico e de informação, proporciona ao leitor, "atento", reflexões sobre o contexto histórico-social no qual se desenvolveu como homem crítico e engajado à cultura do seu povo.

Os textos literários constituem-se a partir de lugares históricos, ou seja, ao escrever e ao ler produzem-se influências que passam por instâncias sociais e culturais de interesses particulares ou gerais. Vive-se em permanente diálogo com os mais variados discursos. E neste vasto movimento da linguagem se busca sustentar teses e pontos de vista. Portanto, quanto maior o diálogo com outros discursos, mais apto se está para compreender a argumentação alheia e para produzir discursos próprios. Nessa interação ampliam-se os horizontes do conhecimento que nunca estarão acabados, pois a cada ponto de chegada, nasce um novo ponto de partida.

Em suma, a linguagem e a literatura se fundem na identidade e no progresso de um povo, resgatando a história de pessoas que fizeram e fazem a história e o desenvolvimento de uma vila, de um município, de um estado, de um país, do mundo, pois são as raízes de um povo que o fazem conhecer e amar sua terra e compreender 
através da linguagem as muitas diferenças existentes entre os povos. Estas, quando conhecidas, tornam mais fácil a convivência humana, porque as diferenças deixam de ser apenas diferenças por serem permeadas de fatos que mostram o quanto as diferentes culturas trazem na sua essência fatos semelhantes, sendo apenas o rótulo uma diferenciação.

Isso tudo marca o trabalho literário que no uso da linguagem supera o puro materialismo da palavra, pois através desta se é capaz de criar e personificar os valores do mundo e da vida.

\section{Referências Bibliográficas}

CANDIDO, Antônio. A literatura e a formação do homem. Ciência e cultura. São Paulo, 1972.

CANDIDO, Antônio. Literatura e cultura de 1900 a 1945. In : Literatura e sociedade. São Paulo: Nacional, 1985.

CÂNDIDO, Antônio. Literatura e sociedade. São Paulo: Nacional, 1967.

GEERTZ, Clifford. A interpretação das culturas. Rio de Janeiro: Guanabara, 1989.

LOPES, Edward. Interpretação do interpretante. Revista brasileira de Semiótica. São Paulo, 1: 43-59, 1974.

ORLANDI, Eni. Discurso e leitura. Campinas: Ed. UNICAMP, 1988.

VELOSO, Mariza \& MADEIRA, Angélica. Leituras Brasileiras: Itinerários no pensamento social e na literatura. Rio de Janeiro: Editora Paz e Terra, 1999.

Bíblia Sagrada. Evangelho Segundo João (Jo. 1, 1) 
